\title{
Effect Investment Opportunity Set on Cost Of Equity Capital : Study of online investment Information Technology in the Indonesian Stock Exchange
}

\author{
Sri Hermuningsih \\ $\left\{\right.$ hermun_feust@yahoo.co.id ${ }^{1}$ \} \\ Faculty of Economy, University of Sarjanawiyata Tamansiswa, Yogyakarta, Indonesia ${ }^{1}$
}

\begin{abstract}
The study aims to analyze disclosure as variable mediating the effects of investment opportunity set on cost of equity capital in the companies listed at lq45 in Indonesian stock exchange.Data analysis exploited secondary data taken from financial report in the period of 2012-2016.Data on stock price was taken from http://www.duniainvestasi.com/bei. Sampling was carried out using purposive sampling method and it was analyzed through the use of partial least square. The results of this study indicate that investment opportunity set provides positive and significant effects on cost of equity capital. Disclosure provides negative and significant effect on cost of equity capital. Investment opportunity set provides indirect effects on cost of equity capital, disclosure. Therefore, the conclusion of this research isdisclosure may mediate the effect of investment opportunity set on cost of equity capital.
\end{abstract}

Keywords: Investment opportunity set, disclosure, cost of equity capital

\section{Introduction}

Every company has a purpose and also different specific target. But the real of company's goal is to maximize company's value that can be measured from the share price of that company. The higher of compay's value means the more prosperous shareholders. To achieve those goals, the capital owners can trust to managerials or it is common called agent. Those managerials are responsible to fund alocation decision both it derives from inside of company and it is from outside of company for investment. The policy of capital structure basically is built from the relationship between decision in selecting source of fund with the type of investment that must be selected by company in order to it is in line with company's goal which is maximizing the prosperity of shareholders who are reflected from company's value or market value from the stock price of company.

To achieve the purpose in that capital structure policy, manager has to be able to collect fund both it sources from inside of company and outside efficiently; in the sense of funding decision that can minimize capital cost charged by company. Capital cost that appears from those funding decision is a consequence which arises directly from decision conducted by manager. When manager uses debt, so capital cost appears is the amount of interest charged by creditor, while if 
manager uses internal fund or fund itself will appears opportunity cost from fund or owner's equity used. Funding decision that is conducted inaccurately will cause fixed cost in the form of high capital cost, then it can impact on the low of company profitability.

Generally, the component of capital cost consists of cost of debt and cost of equity capital. Cost of Debt is return given by company to lender. In other words, it is interest expense that arises from debt financing. Cost of Equity Capital is abbreviated with COEC that is cost incurred by company which gets fund with selling stock. For investor, if COEC is low so it will attract to do investment, because COEC is opportunity cost from the funds invested by investor in a company, so if it can get opportunity cost from fund invested by investor, so investor will be interested to invest their investment in that company.

There are two factors that can be used to decrease COEC, are: 1) Investment Opportunity Set and 2) Disclosure. Investment Opportunity Set which is abbreviated with IOS, it is combination between asset in place and investment selection in the future with the positive of net present value [1].

The selection of investment in the future is not merely only showed by the existence of projects supported by research activities and only development, but it also company's ability more in exploiting the opportunity to take benefit compared than the equal other company in a group of its industries. The selection of investment in the future is related to the level of company growth so it is expected to give the positive aspect for company as the opportunity to invest in the future. The higher of company's ability is unobservable, so it is needed proxy.

However, the chance of company growth can be still seen in investment opportunity that is proxied with some kinds of combination of IOS value which is: (1) Proxy of IOS based on price; (2) Proxy of IOS based on investment; (3) Proxy of IOS based on variance measurement [2].

Second, disclosure is a providing information and a quite explanation about activity result of a business unit. Therefore, those information must be completed, clear, and it can describe economical events precisely that influences to operation result of that business unit. Adequate disclosure is given by company because it has a interest which is the existence of expectation about positive impact from the delivering disclosure. In other parties, investor needs information to assess time and uncertainty of cash flow right now and in the future so it can assess the company and make decision. Company fulfills those necessities by giving information both it is through a required disclosure or volunteer disclosure.

Capital Market Supervisory Bureau and Financial Institution (BAPEPAMLK) is as institution that manages and supervises the implementation of capital market in Indonesia has issued several rules of disclosure that must be done by go public of company.

Those rules are intended to protect the capital owners from the existence of assymmetry information. Company can provide disclosure through annual report that has been managed by mandatory disclosure (Bapepam), and through voluntary disclosure as additional minimum disclosure that has been set.

Mandatory disclosure is disclosure information that must be notified of a company as it is set in the provision (Kep-134/BL/2006) about information disclosure in annual report. Voluntary disclosure is disclosure information beyond mandatory disclosure that is given by company voluntarily to financial report user. Voluntary disclosure is not required by regulation so company is free to select kind of information that will be revealed; assumed by management is relevant in helping decision making. 
Voluntary disclosure is one of ways to improve the credibility of company financial report and to help investor in understanding company business strategy. Voluntary disclosure includes the description of company strategy in long term period, the important and useful of non-financial indicators for the effectiveness of company strategy implementation and it is useful in discussing the correlation between the important indicators with the future earnings. By the existence of voluntary disclosure is expected to financial report users will be more completed the information in understanding operational activity of company and it is more showing company's transparancy [3].

According to theory of agency, there is separation between ownership and controlling in a company that can cause conflict between principal and agent. It can impact the arising of agency cost. The behaviour of moral hazard and asymmetry information can be prevented by agreement with giving incentive in form of financial compensation which is calculated as agency cost, so manager will be motivated to provide disclosures especially voluntary disclosure to decrease agency cost. The cost for supervision by shareholders, the cost is charged by management to get the transparancy report, included independent audit cost and internal controlling are agency cost [4].

Company will reveal information voluntarily if the benefit gained from disclosure information is bigger than its cost. The benefit of that disclosure is obtained because disclosure information of company will help investor and creditor in understanding company condition and it helps in investment decision making. If the benefit that will be achieved by disclosure information is bigger than the cost charged to reveal that, so company will reveal voluntarily those information.

The previous study mentioned that agency theory implicates the existence of assymmetry information between manager as agent and owner (in this case is shareholders) as principal. Assymmetry information appears when manager knows more about internal information and company prospect in the future compared than shareholders and other stakeholders. Related to the improvement of company value, when there is assymmetry information, manager can give signal concerning about company condition to investor in order to maximize the stock value of company. The signal given can be through disclosure information of accounting [5].

The study in order to review the influence of disclosure towards COEC done and it shows that there is negative correlation between disclosure with capital cost [6][7], the high quality of disclosure decreases capital cost [8]. While the high quality of accounting will decrease to COEC [9].

Some studies has been conducted particularly for testing the influence of IOS towards disclosure and the influence of disclosure towards COEC. There are studies conducted as concerning about the influence of IOS towards disclosure policy [10]. The previous study has found also that IOS influences positively and significantly towards disclosure and outside manager [11][12]. With simultanously approach on companies in New Zealand, it has been proven that IOS influences positively and significantly towards the level of voluntary disclosure [13].

Besides that, the previous study has been conducted to review the influence of disclosure level towards equity capital cost [14][15], the influence of disclosure level towards COEC [16][17], the influence of voluntary disclosure and market liquidity towards the correlation between assymmetry information and COEC [18]. Information of accounting, disclosure and cost of capital [8]. The selection of capital allocation of company, the quality of information, and cost of capital [8]. The influence of information level towards equity capital cost in go pulic 
company that is listed in Indonesia stock exchange [19]. The theory of voluntary disclosure and cost of capital [20][21].

One of important decision that a financial manager encounters in terms of the operational sustainability of the company concerns with financing decision or capital structure decision, i.e. the financial decision related to debt composition, preference stock and common stock that the company adopts[22].A manager should be able to perform fund raising, both from internal and external sides of the company.In this case, the financing decision refers to one that is capable to create minimum capital cost that the company should spend. The capital cost that the financing decision produces turns out to be a direct consequence of the decision that the manager makes. The inaccurate financing decision will produce fixed burden, in terms of high capital cost, and in turn may cause lower profitability of the company.

In general, the components of capital cost consist of cost of debtand cost of equity capital. Cost of debtis a returnthat the company should give to lenders. Cost of equity capital may undergo internal increase by holding profit or external increase by selling or issuing new common stock. The company may distribute its after tax profit in the form of dividendor retained earnings. The retained earnings, then, is used for investment (reinvestment) in the company.Its capital cost of retained earnings spent for investment should be calculated.

To attract share holders invest their fund into the company, in addition to the capital cost, they also need transparency on financial report, and this is frequently called as disclosure.

To disclose accounting information is one of important instruments to solve agency problems that management and owner face since it is considered as an effort to minimize asymmetric information.There are two types of asymmetric information:first, is AdverseSelection; it is closely related to the communication issues of internal (manager)to external (investor) sides; second, is MoralHazard; this problem arises due to the the difficulty in supervising and controlling manager's effortto manage the company. This is true since the separation of ownership and control that big companies frequently perform; hence, it is impossible for stakeholders to conduct the level and liquidity of top manager's effortin running the company based on the shareholders' interest; and therefore, this condition encourages the manager to have opportunistic behavior.Related to the increase of company value, when there is asymmetric information, manager may provide investors with a signal concerning the condition of the company to maximize the value of company's stock.The signal can be provided through the disclosureof accounting information.

This study focuses on the testing whether disclosure may mediate the IOS effect on cost of equity capital. This is caused that IOS variable may provide both direct and indirect cost of equity capitalas well, through information disclosure as an intervening variable.

\subsection{The Effects of Investment Opportunity Set (IOS) and Disclosure}

The theory of agency starts from the separation of control and ownership of the company, triggering the conflicts between agents and principals. Such a conflict will, in turn, cause reducing company value[4].

The effect of asymmetric information on non-developing is greater than that on developing company[2][3]SimakBaca secara fonetik. In specific, manager will involve activities that minimize agency cost and hence will maximize company value[23]. 
The Effects of Investment Opportunity Set (IOS)puts positive and significant effects on disclosure[10]. IOSgives positive and significant effect on the level of voluntary disclosure[13]. In the last results of studywas showed that ra company with higher profit development performs higher voluntary disclosure[24]

In this study,IOSexploits six proxies, i.e.: market to book total asset (MTBA) ratio, market to book total equity (MTBE) ratio, earning per share/ price earning (PE) ratio, investment to sales (INVOS) ratio, capital expenditure to book value of asset (CAPTA). IOS can bemeasured by using the six proxies. It is expected that these ratios reflect investment opportunity that the company has, i.e. the higher the ratios of IOS are, the higher the growth opportunity of the company is[25].

When the company shows prosperous growth, the management will send a signal through disclosure. Hence, IOSmay be controlled by the manager. Therefore, hypothesis 1 is proposed as the following: Investment opportunitysetprovides positive effect on COEC.

\subsection{Disclosure on COEC}

Factoraffecting COEC, among others, are disclosure[26], company size[27],and financial leverage[28].Disclosureis a variable that may reduce COEC.The greater the disclosure is, the lower COECis[23][14].The cost of equity capital can be computed in banking corporation by using the three measurement models[29]. However, the most significant model is CAPM.

The effects of voluntary disclosure and market liquidity on the relationship between asymmetric information and COEC indicate that the higher the effect of voluntary disclosure is, the lower the relationship between asymmetric information and COEC[18]. The higher the profit growth and the voluntary disclosure level are, the lower the capital cost of equity will be[24].

The last results of study indicatedthat higher disclosure level will decrease COEC[23][30][31][32][33][9][19]. Voluntary disclosure will decrease cost of capital[20]. Therefore, hypothesis 2 is proposed as the following: Disclosure provides negative effect on COEC.

\subsection{Investment Opportunity Setand COEC}

Investment Opportunity Set (IOS) provides wider guidance stating that company value depends on the spending of the company in the future[1]. The components of company value that is the result of opportunities to make investment in the future turns out to be IOS[3][2]. The association between IOSand disclosure policy have been found [10]. The agency cost of stockholders and manager increase with the total of external stockholders. Public ownership is used to maintain the positive association between IOSand growth options; and hence, it facilitates interpretable infrastructure[34]. Manager must reportsisclosureon the future prospect of the companyto reduce the conflict between stockholders and debtholder[10].

The increasing $\mathrm{P} / \mathrm{E}$ ratio will reduce cost of equity capital[35]. Price earning growth ratio and $\mathrm{P} / \mathrm{E}$ ratio indicate negative correlation with cost of equity[36]. Higher earning per share reduces cost of equity capital[37].IOS provides negative effect on cost of equity capitals [38], increases growth to facilitate external fund raising and reduces capital cost[39].Therefore, hypothesis 2 is proposed as the following: Disclosure may mediate the effect of investment opportunityon cost of equity capital. 


\section{Research Method}

Annual data were gathered from the financial statements of the companies included in LQ45group for 2010-2014 period, and stock prices was taken from www.duniainvestasi.com.To perform hypothesis testing, IOSwascomputed by using the following formula:

\subsection{Price-based IOS proxies involve:}

1 The ratio of the market value of assets to the value of the book (MTBA) $=[$ book value of debt + (outstanding shares $\mathrm{x}$ share price)] / Total assets

2 The ratio of equity market value to the book value $(\mathrm{MTBE})=($ outstanding shares $\mathrm{x}$ share price) / Total equity

3 Share price ratio to earnings per share $(\mathrm{PE})=$ share price $/$ profit per share

\subsection{Investment-based IOS proxies consist of :}

1 Investment to sales ratio (INVOS) $=$ Total fixed assets are tangible $/$ net sales

2 Investment to profit ratio (IOE) $=$ Total fixed assets are tangible / net income

3 The ratio of capital expenditure to book value of total assets (CAPTA) $=$ changes in fixed assets / total book value of assets

COECwas estimated by using Capital Asset Pricing Model (CAPM).

$$
\mathrm{COEC}=\mathrm{R}_{\mathrm{f}}+\beta\left(\mathrm{RM}-\mathrm{R}_{\mathrm{f}}\right)
$$

Note:

COEC = estimated cost of equity capital

$\mathrm{R}_{\mathrm{f}} \quad=$ risk free rate

$\mathrm{RM} \quad=$ market return

$\beta=$ market beta

Disclosure

Mandatory Disclosure

Minimum disclosure that is required by available regulation

Voluntary Disclosure

Disclosure which is released by company beyond the requirements of accounting standards or the regulations of supervisory body

\section{Findings And Discussions}

Table 1 shows the statistical descriptive of variables, consisting of the minimum value, maximum value, averages and standard devition of variable values. 
Tabel 1. Deskriptif statistic

\begin{tabular}{lccccc}
\hline & N & Minimum & Maximum & Average & Std.Deviation \\
\hline MTBA & 172 & 0.08 & 8.30 & 1.8135 & 1.92049 \\
MTBE & 172 & 0.01 & 8.92 & 1.9676 & 1.87768 \\
INVOS & 172 & 0.01 & 5.75 & 1.0534 & 1.22150 \\
PE & 172 & 2.00 & 79.20 & 20.3629 & 15.62090 \\
IOE & 172 & 0.03 & 37.31 & 7.8939 & 9.72763 \\
CAPTA & 172 & 0.00 & 1.93 & 0.9037 & 0.27587 \\
MDISCL & 172 & 0.52 & 0.90 & 0.6624 & 0.05274 \\
VDISCL & 172 & 0.58 & 0.85 & 0.6936 & 0.04267 \\
COEC & 172 & 0.08 & 0.65 & 0.2830 & 0.15642 \\
Valid N (listwise) $=172$ & & & \\
\hline
\end{tabular}

Table 1 explains that the average value of COECwas 0.2830. Then, the average values of IOS variable measured using MTBA, MTBE, INVOS, PE, IOE, CAPTAwere 1.81351.9676, 1.0534, $20.3629,7.8939,0.9037$, respectively. The average values higher than 1 indicate that the company undergoes sound growth opportunity. The average values of disclosurevariable measured using mandatory disclosure, voluntary disclosure were $0.6624,0.6936$, respectively. The average values higher than 0.5 indicate that the company releases moderately high disclosure.

The direct effect level of IOS on COEC was -0.157 and the level of disclosureon COEC was 0.339; hence, the IOS effect on disclosure, the effect of disclosure on COEC was -0.149499 . The level of total effect was $=-0.306499$. The level of total effect of -0.306499 was higher than the direct effect of IOS on COECof - 0.157. It is proved that disclosure serves as mediating variable for the IOS effect on COEC.

Last studys showed that Price Earning ratio (P/E ratio) has inverse correlation with cost of equity capital[40]. Market-to-book equity has negative correlation with cost of equity capital[15]. Increasing $\mathrm{P} / \mathrm{E}$ ratio will decrease cost of equity capital[41][35]. Price earning growth ratio with $\mathrm{P} / \mathrm{E}$ ratio has negative correlation with cost of equity[36]. Higher earning per share reduces cost of equity capital[37].Investment opportunity set provides negative effect on cost of equity capital[38]. The availability of IOS providing profitable returnto controlling stockholders will be greater than the benefit they will receive when discretion (free action to make decision) is taken on the resources of the company[39].

Several findings of this study is expected to be able to provide contribution to the development of capital structure policy theory and its implementation, and to both corporation managersand investorsor prospective investors, as well. The theory on capital structure policy, basically, has been developed based on the correlation of the decision in selecting financial resources and the type of investment that the company should take in accordance with the goal of the company, i.e. to maximize the wealth of the shareholders that is reflected from the company value or market value of the company stock price. 


\section{Conclusions And Implications}

IOS provides positiveand significant effect on disclosure.It means that the greater IOS is, the higher disclosure will be. The theory proposes that in the company with higher investment opportunity when there is asymmetric information, then manager may give its investors with information concerning the company condition to maximize the value of company stock. Disclosure provides negativeand significant effects on COEC; this shows that the higher disclosure is, the lower COEC will be.

COEC is highly important to be noted by managements. The lower COEC will attract investorsto make their investment in the company.Higher IOS indirectly will decrease COEC since the higher disclosure is, the more transparent the company will be.

This will minimize the existing asymmetric information in the company, and hence it also reducesCOEC. It is expected that such a theory can be adopted as a reference in the future studies on the factors affecting COEC. The understanding on COEC, particularly on IOS, i.e. IOS is really should be done through disclosureto provide effect on COEC. With this finding, studies on capital market on Indonesia will be increasingly rich and perfect.

\section{References}

[1] S. C. Myers, "Capital structure," Journal of Economic perspectives, vol. 15, no. 2, pp. 81-102, 2001.

[2] M. J. Barclay, C. W. Smith, and R. L. Watts, "The determinants of corporate leverage and dividend policies," Journal of Financial Education, pp. 1-15, 1997.

[3] J. J. Gaver and K. M. Gaver, "Additional evidence on the association between the investment opportunity set and corporate financing, dividend, and compensation policies," Journal of Accounting and economics, vol. 16, no. 1-3, pp. 125-160, 1993.

[4] M. C. Jensen and W. H. Meckling, "Theory of the firm: Managerial behavior, agency costs and ownership structure," Journal of financial economics, vol. 3, no. 4, pp. 305-360, 1976.

[5] P. T. Komalasari and Z. Baridwan, "Asimetri informasi dan cost of equity capital," Jurnal Riset Akuntansi Indonesia, vol. 4, no. 1, pp. 64-81, 2001.

[6] J. L. McKinnon and L. Dalimunthe, "Voluntaru disclosure of segmet information by Australian diversified compnies," Accounting and Finance, vol. 33, pp. 33-50, 1993.

[7] W. Gebhardt, L. CMC, and S. B, "Toward an implied cost of capital," Journal of accounting research, vol. 39, pp. 135-176, 2001.

[8] R. Lambert, C. Leuz, and R. E. Verrecchia, Accounting information, disclosure, and the cost of capital. Wharton School Working Paper, 2006.

[9] Yang Li, D. Stokes, S. Taylor, and L. Wong, "Audit quality, earning quality and the cost of equity capital,” 2009. [Online]. Available: www.afaanz.org. [Accessed: 30-Aug-2018].

[10] S. F. Cahan and M. Hossain, "The investment opportunity set and disclosure policy choice: Some Malaysian evidence,” Asia Pacific Journal of Management, vol. 13, no. 1, pp. 65-85, 1996.

[11] M. Hossain, S. F. Cahan, and M. B. Adams, "The investment opportunity set and the voluntary use of outside directors: new zealand evidence," Accounting and Business Research, vol. 30, no. 4, pp. 263-273, 2000.

[12] I. Subekti and I. W. Kusuma, "Assosiasi antara set kesempatan investasi dengan kebijakan pendanaan dan dividen perusahaan, serta implikasinya pada perubahan harga saham," in SNA IV, IAI, 2000, pp. 820845. 
[13] M. Hossain, K. Ahmed, and J. M. Godfrey, "Investment opportunity set and voluntary disclosure of prospective information: A simultaneous equations approach," Journal of Business Finance \& Accounting, vol. 32, no. 5-6, pp. 871-907, 2005.

[14] C. A. Botosan, "The effect of disclosure level on the cost of equity capital and stock market liquidity.," 1995.

[15] E. F. Fama and K. R. French, "The cross-section of expected stock returns," the Journal of Finance, vol. 47, no. 2, pp. 427-465, 1992.

[16] R. J. Bloomfield and T. J. Wilks, "Disclosure effects in the laboratory: Liquidity, depth, and the cost of capital," The Accounting Review, vol. 75, no. 1, pp. 13-41, 2000.

[17] Juniarti and F. Yunita, "Pengaruh tingkat disclosure terhadap biaya ekuitas," Jurnal Akuntansi Petra, vol. 5, no. 2, 2003.

[18] A. A. Mardiyah, "Pengaruh pengungkapan sukarela dan likuiditas pasar terhadap hubungan antara informasi asimetrik dan cost of equity capital." 2004.

[19] B. S. Puspita, "Pengaruh tingkat pengungkapan informasi terhadap biaya modal ekuitas pada perusahaan go public yang terdaftar di bursa efek indonesia," Universtas Airlangga Surabaya, 2009.

[20] E. Cheynel, "A theory of voluntary disclosure and cost of capital," Review of Accounting Studies, vol. 18 , no. 4, pp. 987-1020, 2013.

[21] Dhaliwal, O. Z. Li, A. Tsang, and Y. G. Yang, "Voluntary nonfinancial disclosure and the cost of equity capital: the initiation of corporate social responsibility report," 2010.

[22] Y. Prabansari and H. Kusuma, Faktor-Faktor yang Mempengaruhi Struktur Modal Perusahaan Manufaktur Go Public di Bursa Efek Jakarta, Edisi Khus. 2005.

[23] D. Diamond and R. Verrecchia, "Disclosure, Liquidity, andthe Cost of Euqity Capital," J.] Jounnal of Finance, vol. 46, no. 4, pp. 132-559, 1991.

[24] M. Akhtaruddin and M. Hossain, "Investment opportunity set, ownership control and voluntary disclosures in Malaysia," Joaag, vol. 3, no. 2, pp. 25-39, 2008.

[25] S. Kallapur and M. A. Trombley, "The association between investment opportunity set proxies and realized growth," Journal of Business Finance \& Accounting, vol. 26, no. 3-4, pp. 505-519, 1999.

[26] C. A. Botosan, "Disclosure level and the cost of equity capital," Accounting review, vol. 72, no. 3, pp. 323-349, 1997.

[27] F. D. Andadi, "Asimetri information and cost of equity capital pada perusahaan go public di bursa efek jakarta (BEJ)," Universitas Brawijaya Malang, 2006.

[28] Madichah, "Pengaruh earning per share (eps), dividen per share (dps) dan financial leverage (fl) terhadap harga saham perusahaan.” 2005.

[29] E. J. Green, J. A. Lopez, and Z. Wang, "Formulating the imputed cost of equity capital for priced services at Federal reserve Banks," FRBNY economic policy review. 2003.

[30] P. Handa and S. C. Linn, "Arbitrage pricing with estimation risk," Journal of Financial and Quantitative Analysis, vol. 28, no. 1, pp. 81-100, 1993.

[31] J. L. Coles, U. Loewenstein, and J. Suay, “On equilibrium pricing under parameter uncertainty,” Journal of Financial and Quantitative Analysis, vol. 30, no. 3, pp. 347-364, 1995.

[32] C. A. Botosan and M. Plumlee, "Disclosure level and expected cost of equity capital: An examination of analysts' rankings of corporate disclosure and alternative methods of estimating expected cost of equity capital," Social Science Research Network Electronic Paper Collection, 2000.

[33] C. Leuz and R. E. Verrecchia, "The economic consequences of increased disclosure," Journal of accounting research, vol. 38, pp. 91-124, 2000.

[34] E. F. Fama and M. C. Jensen, "Agency problems and residual claims," The Journal of Law and Economics, vol. 26, no. 2, pp. 327-349, 1983.

[35] B. Chowdhry and S. Titman, "Why real interest rates, cost of capital and price/earnings ratios vary across countries," Journal of International money and Finance, vol. 20, no. 2, pp. 165-189, 2001. 
[36] P. D. Easton, "PE ratios, PEG ratios, and estimating the implied expected rate of return on equity capital," The accounting review, vol. 79, no. 1, pp. 73-95, 2004.

[37] C.-J. Kim, J. C. Morley, and C. R. Nelson, "Is there a positive relationship between stock market volatility and the equity premium?," Journal of Money, Credit and banking, vol. 36, no. 3, pp. 339-360, 2004.

[38] S. Hermuningsih, Pengantar Pasar Modal Indonesia. Yogyakarta: UPP STIM YKPN, 2012.

[39] A. Durnev and E. H. Kim, "To steal or not to steal: Firm attributes, legal environment, and valuation," The Journal of Finance, vol. 60, no. 3, pp. 1461-1493, 2005.

[40] D. A. Goodman and J. W. Peavy, "The risk universal nature of the P/E effect," The Journal of Portfolio Management, vol. 11, no. 4, pp. 14-16, 1985.

[41] C. Firer, "The P/E ratio and the cost of equity capital," Investment Analysts Journal, vol. 22, no. 38, pp. 43-47, 1993. 